EGU21-2321

https://doi.org/10.5194/egusphere-egu21-2321

EGU General Assembly 2021

(c) Author(s) 2021. This work is distributed under

the Creative Commons Attribution 4.0 License.

\title{
Core-log-seismic integration in metamorphic rocks at the ICDP drilling project COSC-1, Sweden
}

\author{
Judith Elger ${ }^{1}$, Christian Berndt ${ }^{1}$, Felix Kästner ${ }^{1,2}$, Simona Pierdominici ${ }^{2}$, Jochem Kück ${ }^{2}$, Bjarne S. G. \\ Almqvist $^{3}$, Christopher Juhlin ${ }^{3}$, and Henning Lorenz ${ }^{3}$ \\ ${ }^{3}$ Department of Earth Sciences, Uppsala University, Uppsala, Sweden
}

Continental collision causes deformation in the crust along shear zones. However, the physical and chemical conditions at which these zones operate and the deformation processes that enable up to hundreds of $\mathrm{km}$ of tectonic transport are still unclear because of the depth at which they occur and the challenges in imaging them. Ancient exhumed collision zones allow us to investigate these processes much better, for example at the COSC-1 borehole in the central Scandinavian Caledonides. This study combines data from the COSC-1 borehole, such as downhole logging and zero-offset vertical seismic profile data, with 2D and 3D seismic measurements to provide constraints on the spatial lithological and textural configuration of the Seve Nappe Complex. This is one of the few studies that shows that core-log-seismic integration in metamorphic rocks allows to identify the spatial distribution of major lithological units, even though the methodology was originally developed for sedimentary basins in the hydrocarbon industry. Especially gamma ray logs in combination with density data are powerful tools to distinguish between mafic and felsic lithologies in log-core correlation. Reflections in the Seve Nappe Complex are not as distinct as in greater depths but continuous, and our results indicate that they are primarily caused by compositional rather than textural changes. Several of the reflections can be linked to magmatic intrusions, which have been metamorphically overprinted. Their setting indicates that the Seve Nappe Complex consists of the remnants of a volcanic continental margin. It appears that in spite of the metamorphic overprint around 417+/-9 Ma, the original configuration of the volcanic passive margin is partly preserved in the Seve Nappe Complex and that it outlasted continentcontinent collision, including the nappe emplacement. Thus, an integration of borehole and threedimensional geophysical data can image lithological changes that can then be extrapolated in three dimensions to arrive at a better understanding of the composition and geometry at midcrustal levels. Furthermore, our results suggest that ductile-deformed middle crustal reflectivity is primarily a function of pre-orogenic lithological variations which has to be considered when deciphering mountain building processes. 